\title{
Socio-demographic, social, cognitive, and emotional correlates of adherence to physical distancing during the COVID-19 pandemic: a cross-sectional study
}

\author{
Jean-Philippe Gouin ${ }^{1}(\mathbb{D}) \cdot$ Sasha MacNeil $^{1} \cdot$ Andrew Switzer $^{1} \cdot$ Emily Carrese-Chacra $^{1} \cdot$ Fabien Durif $^{2} \cdot$ Bärbel Knäuper $^{3}$
}

Received: 14 May 2020 / Accepted: 16 November 2020 / Published online: 19 January 2021

(C) The Canadian Public Health Association 2021

\begin{abstract}
Objectives In order for physical distancing directives to be effective at lowering and flattening the epidemic peak during a pandemic, individuals must adhere to confinement guidelines. Recent reviews highlight the paucity of research on empirical correlates of adherence to physical distancing and quarantine directives.

Methods In this cross-sectional study, 1003 individuals were recruited using quota sampling to form a sample approximately representative of the population of Quebec (Canada) in terms of age, gender, and urbanicity. Participants completed an online survey on adherence to physical distancing during the COVID-19 pandemic. This survey evaluated socio-demographic, health, cognitive, emotional, and social factors related to physical distancing.

Results Individuals aged 70 and older $(\mathrm{OR}=1.67,95 \% \mathrm{CI}=1.04-2.67)$, women $(\mathrm{OR}=1.35,95 \% \mathrm{CI}=1.02-1.79)$, and those who were not essential workers $(\mathrm{OR}=3.28,95 \% \mathrm{CI}=2.24-4.81)$ reported more physical distancing. Injunctive personal norms $(\mathrm{OR}=1.67,95 \% \mathrm{CI}=1.23-2.31)$, perceived benefits of physical distancing to others $(\mathrm{OR}=1.47,95 \% \mathrm{CI}=1.12-1.93)$, and descriptive social norms $(\mathrm{OR}=1.26,95 \% \mathrm{CI}=1.04-1.52)$ were independent predictors of adherence status. Individuals adhered more to physical distancing if they believed that it was their civic duty to do so and that physical distancing helped protect others, and if they perceived that most other people were following these directives. In contrast, perceived personal risk and emotional factors were not independently related to physical distancing.

Conclusion These results highlight the importance of health beliefs and perceived social norms in shaping responses to physical distancing directives. These findings offer insights into ways to frame public health communications to promote physical distancing during a pandemic.
\end{abstract}

\section{Résumé}

Objectifs Afin d'assurer l'efficacité des directives de distanciation physique à aplatir la courbe épidémique lors d'une pandémie, les membres de la communauté doivent respecter les règles de confinement. Des revues de la littérature mettent en évidence le manque de données empiriques sur les corrélats de l'adhérence aux directives de distanciation physique et de quarantaine.

Méthodes Dans cette étude transversale, 1003 individus ont été recrutés en utilisant une méthode d'échantillonnage par quota afin de constituer un échantillon approximativement représentatif de la population du Québec, Canada, en termes d'âge, de genre, et de ruralité. Les participants ont complété une enquête en ligne sur l'adhérence à la distanciation physique durant la pandémie de la COVID-19. Cette enquête a évalué l'association entre l'adhérence à la distanciation physique et les facteurs sociodémographiques, médicaux, cognitifs, émotionnels, et sociaux.

Résultats Les individus âgés de 70 ans et plus ( $\mathrm{RC}=1,67$, IC95\% $=1,04-2,67)$, les femmes $(\mathrm{RC}=1,35, \mathrm{IC} 95 \%=1,02-1,79)$ et ceux qui n'étaient pas des travailleurs essentiels $(\mathrm{RC}=3,28, \mathrm{IC} 95 \%=2,24-4,81)$ ont rapporté plus de distanciation physique. Les normes injonctives personnelles ( $\mathrm{RC}=1,67, \mathrm{IC} 95 \%=1,23-2,31)$, la perception de bénéfices de la distanciation physique pour les autres $(\mathrm{RC}=1,47, \mathrm{IC} 95 \%=1,12-1,93)$, et les normes sociales descriptives $(\mathrm{RC}=1,26, \mathrm{IC} 95 \%=1,04-1,52)$ étaient des

Jean-Philippe Gouin

jp.gouin@concordia.ca

1 Concordia University, 7141 Sherbrooke West, Montreal, Quebec H4B 1R6, Canada
2 Université du Québec à Montréal, Case postale 8888, succursale Centre-ville, Montreal, Quebec H3C 3P8, Canada

3 McGill University, 845 Sherbrooke West, Montreal, Quebec H3A 0G4, Canada 
facteurs prédictifs indépendants de l'adhérence. L'adhérence à la distanciation physique était plus probable chez les individus qui croyaient qu'il était de leur devoir civique de respecter les directives et que la distanciation physique aidait à protéger les autres, et qui percevaient que la plupart des autres personnes respectaient aussi ces directives. La perception du risque personnel et les facteurs émotionnels n'étaient pas associés de façon indépendante à la distanciation physique.

Conclusion Ces résultats soulignent l'importance des croyances sur la santé et des normes sociales perçues dans la réponse aux directives de distanciation physique. Ces résultats suggèrent différentes façons d'optimiser la présentation des communications de santé publique afin de promouvoir la distanciation physique lors d'une pandémie.

Keywords Physical distancing $\cdot$ Health beliefs $\cdot$ Social norms $\cdot$ Behaviour change $\cdot$ Health communication $\cdot$ COVID-19

Mots-clés Distanciation physique $\cdot$ croyances sur la santé $\cdot$ normes sociales $\cdot$ changement de comportement $\cdot$ communication en santé publique · COVID-19

\section{Introduction}

Severe acute respiratory syndrome coronavirus 2 (SARS$\mathrm{CoV}-2$ ) is a contact-transmissible infectious disease that is transmitted via close contact between individuals (Bi et al. 2020). During the spring of 2020 , about 60,000 individuals were diagnosed with COVID-19 in Quebec, resulting in 5687 deaths (Gouvernement du Québec 2020). Governments around the world imposed physical distancing measures to decrease person-to-person COVID-19 transmission. In Quebec, physical distancing directives included keeping a physical distance between individuals by staying at home, minimizing non-essential travel, avoiding having visitors, avoiding social gatherings, and staying $2 \mathrm{~m}$ away from others while in public (Gouvernement du Québec 2020). The efficacy of physical distancing directives at lowering and flattening the epidemic peak largely depends on the population's adherence to these measures (Anderson et al. 2020). Recent reviews highlight the paucity of research on predictors of adherence to physical distancing during pandemics (Gherson et al. 2018; Webster et al. 2020; Bish and Michie 2010).

Social-cognitive models of health behaviour change highlight that, regardless of objective risk, individual subjective appraisals or beliefs regarding a health threat influence adherence to sanitary directives (Carpenter 2010; Rivis and Sheeran 2003). The health belief model posits that individuals will be more motivated to adhere to physical distancing if they believe that they are susceptible to get infected with SARS-CoV-2, that COVID-19 would be dangerous for them, that these preventive measures would be effective in reducing the health threat, and that they perceive no strong barriers to implementing these sanitary directives (Rosenstock 1974). A meta-analysis across preventive health behaviours indicated that perceived benefits and barriers were more strongly related to adherence, while there is a weak association with perceived severity, and no association with perceived susceptibility (Carpenter 2010). For preventive behaviours relevant to infectious respiratory diseases (e.g., wearing face masks), perceived illness severity and perceived benefits of the preventive actions were more strongly associated with adherence (Bish and Michie 2010).

Social-cognitive models of behaviour change typically focus on the appraisals of health threat on the self rather than on collective well-being. However, a pandemic poses a significant health threat to entire communities, which may lead to an emergent shared social identity (Drury et al. 2019). This sense of common fate can shift the boundaries of in-group and out-group membership, lead to greater concerns for others affected by the pandemic, and facilitate collective action. In this context, a person may not only consider the benefits of physical distancing to themselves but also the benefits to others. Relatedly, messages focusing on protecting others rather than oneself from health risk were more effective in increasing hand washing in the hospital setting (Grant and Hofmann 2011). Therefore, beliefs that physical distancing is effective at protecting others and solving the ongoing crisis may be related to adherence to sanitary measures during a pandemic.

Perceived social norms, the implicit rules that constrain social behaviours and underlie the felt social pressure to enact a given behaviour within a group, are also key determinants of the adoption of preventive health measures (Cialdini and Goldstein 2004). Social norms encompass descriptive social norms (i.e., the extent to which the individual perceives that other people are engaging in the preventive behaviour), as well as injunctive social norms (i.e., the extent to which the individual perceives that close others would approve or disapprove the behaviour). A meta-analysis indicated that both descriptive and injunctive social norms are independently associated with the intention to engage in health behaviours (Rivis and Sheeran 2003). In addition, injunctive personal norms, or moral norms, may be particularly important when predicting behaviour that has consequences for the welfare of others, especially during a pandemic (Drury et al. 
2019; Manstead 2000). Injunctive personal norms reflect the internalized moral rules involving self-approval of a given behaviour and an ascription of responsibility of the self to engage in certain prosocial behaviour (Manstead 2000). Such perceived social norms may thus independently predict physical distancing.

Prior reviews highlight that individuals are at greater risk of experiencing feelings of loneliness and increased psychological distress during periods of quarantine (Brooks et al. 2020). Although greater state anxiety is associated with increased adherence to preventive behaviours during a pandemic (Bish and Michie 2010), increased depressive symptoms and loneliness have been associated with poorer adherence to medical recommendations (DiMatteo et al. 2000; Segrin and Passalacqua 2010). Whether emotional distress is associated with adherence to physical distancing is unknown.

The goal of this exploratory study was to identify empirical correlates of adherence to physical distancing directives during the COVID-19 pandemic. Prior studies indicate that age, gender, marital status, education, employment status, household composition, caregiving responsibilities, living in a rural setting, medical status, and exposure to someone infected with the virus are socio-demographic and health factors that influence adherence to preventive behaviours against respiratory illnesses (Bish and Michie 2010; Leung et al. 2003; Taylor et al. 2009; Webster et al. 2020). This study examined the independent contributions of health beliefs about COVID-19 and physical distancing, perceived social norms, and emotional distress, over and above these socio-demographic and health characteristics.

\section{Methods}

\section{Participants and study design}

In this cross-sectional study, 1003 participants who are part of a web panel maintained by a market research firm (MBA Recherche) completed an online survey about COVID-19 in English or in French. Eligibility criteria consisted of being at least 18 years of age and currently living in Quebec. An invitation to complete the survey was sent to 21,885 individuals within the web panel. Sampling quotas were then used for follow-up invitations to ensure the recruitment of a sample representative of the population of Quebec in terms of age, gender, and urbanicity. Interested participants had to read and electronically sign the consent form in order to access the study survey. Of the 1701 individuals who read the consent, approximately $20 \%$ did not sign the consent form, $12 \%$ were prevented from completing the survey to respect sampling quotas, $9 \%$ agreed to participate but dropped out before providing data on the variables of interest, and 59\% agreed to participate and fully completed the survey. When completing the online survey, participants increased their likelihood of receiving a quarterly cash prize drawn among members of the web panel. Individuals aged 18 through $89(M=48.92, S D=16.23)$ participated in the study, with $10.5 \%$ being 70 years and older. The sample was $52.1 \%$ female, and $36.5 \%$ completed a university degree. All participants completed the survey between April 7 and 15, 2020, 23-32 days after the beginning of the physical distancing directives in Quebec. This study was approved by Concordia University institutional ethics review board (\#30012927).

\section{Measures}

Socio-demographic characteristics Socio-demographic factors included: age; gender; education; household composition; caregiving status (i.e., living with young children, adults with disability, or older adults requiring daily physical assistance); civil status; close others' COVID-19 diagnosis; health risk status defined as having a respiratory, cardiac, or immunosuppression-related medical condition; and being an essential worker who is working outside of home during the confinement period. Population density was imputed using postal codes. Municipalities were categorized as rural, a small or medium population centre, or a large population centre based on Statistics Canada's (2017) classification.

Adherence to physical distancing Participants rated their adherence to governmental physical distancing directives in the last 2 weeks. Five items evaluating the extent to which participants: minimized contact with others by staying home, minimized non-essential errands outside the home, avoided receiving guests at home, avoided social gatherings with more than two people, and stayed at least $2 \mathrm{~m}$ away from others when out in public, were assessed using a 5-point Likert scale (1, never; 2, rarely; 3 , sometimes; 4, often; and 5, almost always). Items were averaged to provide an overall measure of adherence to physical distancing (Cronbach's alpha $=0.78)$. Given that about half of the sample reported almost always adhering to physical distancing, this variable was dichotomized for the multivariate analyses.

Health beliefs Participants completed nine items assessing beliefs regarding COVID-19 and physical distancing using a 5-point Likert scale ranging from 1 (not at all) to 5 (extremely). Three items assessed the extent to which participants perceived they were susceptible to being infected by the virus (perceived susceptibility), and that the 
virus was dangerous for them (perceived severity for oneself) or for their community (perceived severity for others). To assess perceived benefits, participants indicated the extent to which they believed that physical distancing was effective at protecting them from the virus (benefits for oneself) and protecting vulnerable others, and solving the ongoing pandemic (benefits for others; Cronbach alpha $=0.84)$. To assess perceived barriers, participants rated the extent to which they found the recommendations financially costly for themselves, frustrating and unpleasant, and difficult to apply in their daily life $($ Cronbach's alpha $=0.75)$.

Perceived social norms To measure descriptive social norms, participants indicated the extent to which they perceived that others in their community were respecting physical distancing directives on a 5-point Likert-type rating scale ranging from 1 (not at all) to 5 (extremely). To measure injunctive social norms, participants indicated the extent to which they thought their close friends and family would (dis)approve if they learned that they did not respect physical distancing recommendations on a scale ranging from 1 (they would approve) to 5 (they would very much disapprove). To assess injunctive personal norms, participants indicated to which extent they believed it was their civic duty to follow these directives on a 5-point Likert scale ranging from 1 (not at all) to 5 (extremely).

Emotional well-being Emotional distress was assessed using a short version of the Patient Health Questionnaire (Kroenke et al. 2009). This scale includes two items measuring symptoms of depression and two items measuring anxious symptoms (Cronbach's alpha $=0.88$ ). The ThreeItem Loneliness Scale (Hughes et al. 2004) assessed perceived loneliness. Participants responded to which extent they felt left out, lonely, or lacked companionship in the last 2 weeks $($ Cronbach's alpha $=0.82)$.

\section{Statistical analyses}

Hierarchical logistic regression identified independent predictors of adherence to physical distancing directives using JASP Version 0.12.1. The first step examined sociodemographic and health factors, the second step included health beliefs, the third step examined social norms, and the last step included emotional factors. Nagelkerke pseudo $\mathrm{R}^{2}$ assessed model fit. Age was coded as 70 and older given that specific governmental directives were directed at this age group (Gouvernement du Québec 2020). Continuous variables were centred to facilitate interpretation. Eight participants with missing data were excluded from the analysis (final $n=1003$ ). Alpha level was set at 0.05 .

\section{Results}

Descriptive statistics for socio-demographic and health characteristics as well as adherence to physical distancing directives are presented in Table 1 . About $6.4 \%$ of the sample reported adhering sometimes or less often to physical distancing, $45.2 \%$ reported adhering often to physical distancing, and $48.4 \%$ reported that they almost always adhered to all physical distancing directives. Individuals who were younger $(p<0.001, d=0.48)$, were male $(p=$ $0.005, d=0.21)$, had at least one household member requiring physical assistance $(p=0.005, d=0.24)$, had no COVID-19 health risks ( $p=0.022, d=0.15)$, knew someone with a COVID-19 diagnosis ( $p=0.046, d=0.18)$, or were essential workers $(p<0.001, d=0.61)$ reported less overall adherence. In terms of psychological distress, about $16 \%$ of participants reported clinically significant anxious symptoms and $13.4 \%$ reported clinically significant depressive symptoms. Bivariate associations among the study variables are described in Appendix 1.

A logistic regression model identified independent correlates of adherence to physical distancing, as described in Table 2. In the first step examining socio-demographic and health factors, the Nagelkerke pseudo $\mathrm{R}^{2}$ was 0.085 . Socio-demographic factors independently related to more physical distancing included being 70 years or older, being female, and not being an essential worker. Population density, education, household composition, caregiving status, relationship status, health risk, or close others' COVID-19 diagnosis were not independently associated with physical distancing. In the second step examining health beliefs, the Nagelkerke pseudo $\mathrm{R}^{2}$ increased by 0.087. Among the health beliefs, perceived benefits to oneself and to others were significantly associated with physical distancing. Perceived severity for self was marginally associated with physical distancing, but perceived severity for others and perceived barriers were not significantly related to adherence status. In the third step evaluating social norms, the Nagelkerke pseudo $\mathrm{R}^{2}$ increased by 0.029 . Descriptive social norms and injunctive personal norms were independently associated with adherence status, but not injunctive social norms. In the last step examining emotional factors, the Nagelkerke pseudo $\mathrm{R}^{2}$ increased by 0.01 . Neither emotional distress nor loneliness was independently associated with physical distancing.

In the fully adjusted model, age, gender, essential worker status, perceived benefits of physical distancing to others, descriptive social norms, and injunctive personal norms remained independently associated with adherence status. Exploratory analyses using each individual physical distancing directive were also conducted. Overall, the pattern of results was similar across different 
Table 1 Socio-demographic, health, and adherence to physical distancing characteristics $(N=1003)$

\begin{tabular}{|c|c|c|c|}
\hline & & $n$ & $\%$ \\
\hline \multirow[t]{6}{*}{ Age (years) } & $18-29$ & 158 & 15.8 \\
\hline & $30-39$ & 144 & 14.4 \\
\hline & $40-49$ & 196 & 19.5 \\
\hline & $50-59$ & 191 & 19.0 \\
\hline & $60-69$ & 209 & 20.8 \\
\hline & $70+$ & 105 & 10.5 \\
\hline \multirow[t]{2}{*}{ Gender } & Male & 480 & 47.9 \\
\hline & Female & 523 & 52.1 \\
\hline \multirow[t]{4}{*}{ Highest education } & Primary school & 8 & 0.8 \\
\hline & Secondary school & 285 & 28.4 \\
\hline & College/undergraduate & 627 & 62.5 \\
\hline & Post-graduate & 83 & 8.3 \\
\hline \multirow[t]{2}{*}{ Household composition } & Lives alone & 189 & 18.8 \\
\hline & Lives with other(s) & 814 & 81.2 \\
\hline \multirow[t]{2}{*}{ Caregiving status $^{\mathrm{a}}$} & No one & 836 & 83.4 \\
\hline & One or more person(s) & 167 & 16.7 \\
\hline \multirow[t]{2}{*}{ Civil status } & Single & 368 & 36.7 \\
\hline & In a relationship & 635 & 63.3 \\
\hline \multirow[t]{2}{*}{ Close others' COVID-19 diagnosis ${ }^{\mathrm{b}}$} & No & 835 & 83.3 \\
\hline & Yes & 168 & 16.8 \\
\hline \multirow[t]{2}{*}{ Health risk status ${ }^{\mathrm{c}}$} & Low risk & 639 & 63.7 \\
\hline & High risk & 364 & 36.3 \\
\hline \multirow[t]{2}{*}{ Essential worker status ${ }^{\mathrm{d}}$} & Non-essential worker & 845 & 84.3 \\
\hline & Essential worker & 158 & 15.8 \\
\hline \multirow[t]{3}{*}{ Population density } & Rural & 221 & 22.0 \\
\hline & $\begin{array}{l}\text { Small and medium } \\
\text { population centres }\end{array}$ & 50 & 5.0 \\
\hline & Large population centre & 732 & 73.0 \\
\hline \multicolumn{4}{|l|}{ Adherence to physical distancing } \\
\hline \multirow{5}{*}{$\begin{array}{l}\text { Minimize contact with others } \\
\text { by staying home }\end{array}$} & Never & 16 & 1.6 \\
\hline & Rarely & 31 & 3.1 \\
\hline & Sometimes & 55 & 5.5 \\
\hline & Often & 237 & 23.6 \\
\hline & Almost always & 664 & 66.2 \\
\hline \multirow{5}{*}{$\begin{array}{l}\text { Minimize non-essential travel } \\
\text { outside of home }\end{array}$} & Never & 4 & 0.4 \\
\hline & Rarely & 7 & 0.7 \\
\hline & Sometimes & 55 & 5.5 \\
\hline & Often & 276 & 27.5 \\
\hline & Almost always & 661 & 65.9 \\
\hline \multirow[t]{5}{*}{ Avoid home visitors } & Never & 6 & 0.6 \\
\hline & Rarely & 7 & 0.7 \\
\hline & Sometimes & 22 & 2.2 \\
\hline & Often & 87 & 8.7 \\
\hline & Almost always & 881 & 87.8 \\
\hline \multirow[t]{5}{*}{ Avoid social gatherings of $>2$ people } & Never & 8 & 0.8 \\
\hline & Rarely & 7 & 0.7 \\
\hline & Sometimes & 28 & 2.8 \\
\hline & Often & 87 & 8.7 \\
\hline & Almost always & 873 & 87.0 \\
\hline
\end{tabular}


Table 1 (continued)

\begin{tabular}{|c|c|c|c|}
\hline & & $n$ & $\%$ \\
\hline \multirow{5}{*}{$\begin{array}{l}\text { Maintain 2-metre distance from others } \\
\text { when outside of home }\end{array}$} & Never & 2 & 0.2 \\
\hline & Rarely & 6 & 0.6 \\
\hline & Sometimes & 42 & 4.2 \\
\hline & Often & 194 & 19.3 \\
\hline & Almost always & 759 & 75.7 \\
\hline \multirow{5}{*}{$\begin{array}{l}\text { Adherence to physical distancing: } \\
\text { composite score }\end{array}$} & Never & 1 & 0.1 \\
\hline & Rarely & 10 & 1 \\
\hline & Sometimes & 53 & 5.3 \\
\hline & Often & 454 & 45.3 \\
\hline & Almost always & 485 & 48.4 \\
\hline
\end{tabular}

${ }^{a}$ Whether participants share a household with one or more persons requiring daily physical assistance (young children, adults with disability, older adults)

${ }^{\mathrm{b}}$ Whether participants know someone diagnosed with COVID-19

${ }^{\mathrm{c}}$ Whether participants have a respiratory, cardiac, or immunosuppression-related medical condition

${ }^{\mathrm{d}}$ Whether participants are essential workers working outside of the home during the confinement period

physical distancing directives (see Appendix 2). However, essential worker status was associated with poorer adherence to some forms of physical distancing likely due to constraints related to the nature of their work. Sensitivity analyses were conducted by repeating the analyses without essential workers. In the subsample without essential workers, injunctive personal norms $(\mathrm{OR}=2.01,95 \% \mathrm{CI}$ [1.49-2.72], $p<0.001)$, perceived benefits to others $(\mathrm{OR}=1.52,95 \%$ CI [1.16-1.99], $p=0.002)$, and descriptive social norms $(\mathrm{OR}=1.29,95 \%$ CI [1.04-1.60], $p=$ 0.019 ) remained independent predictors of physical distancing.

\section{Discussion}

The goal of the current study was to examine independent socio-demographic, health, social, cognitive, and emotional correlates of adherence to physical distancing directives during the COVID-19 pandemic. Individuals over the age of 70, women, and those who were not essential workers reported adhering more to physical distancing directives. Individuals were also more likely to engage in physical distancing if they: believed that physical distancing helps to protect vulnerable individuals and to solve the ongoing crisis; believed that it is their civic duty to adhere to these directives; perceived that most other people were following these directives. In contrast, perceived personal risk and emotional distress were not independently associated with physical distancing. These results identify potential cognitive and social targets for health communication aimed at promoting physical distancing.

Injunctive personal norms assessed via the sense of civic duty to adhere to governmental directives was one of the strongest predictors of adherence to physical distancing. These results dovetail with findings from qualitative studies (Cava et al. 2005; DiGiovanni et al. 2004). A meta-analysis also indicated that personal injunctive or moral norms are independent predictors of adherence for preventive actions that have consequences for the welfare of others (Rivis et al. 2009). In an experimental study, Facebook messages appealing to one's deontological moral norms (i.e., stating that it is your duty and responsibility to stay home to protect your families, friends, and fellow citizens from COVID-19) were more likely to be shared with others than non-moral messages (Everett et al. 2020). Interventions appealing to one's sense of duty and responsibility toward society may then promote physical distancing during a pandemic.

Perceived benefits of physical distancing for protecting vulnerable others and solving the ongoing crisis was also an independent correlate of physical distancing. Prior work indicates that the perceived benefits of a given preventive action are associated with adherence (Carpenter 2010). However, it was not the perceived benefits for protecting oneself but rather the benefits for protecting others and solving the situation that was independently associated with adherence in this study. The sense of common fate experienced during a pandemic may lead to an emergent shared social identity that increases care and concern for others, sometimes referred to as a "disaster community" (Drury et al. 2019). Evolutionary, 


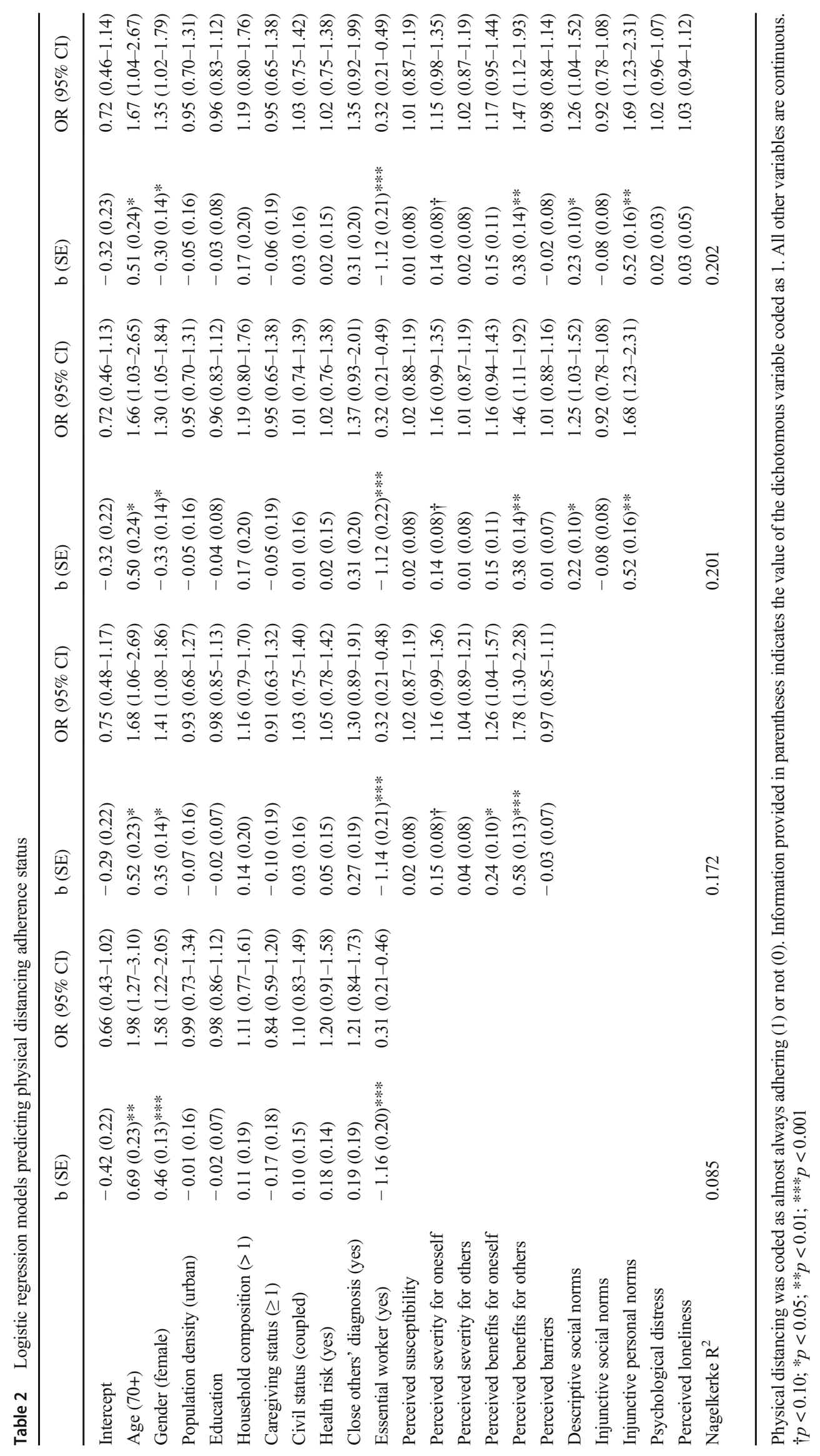


collective threats to survival are best managed if groups give themselves clear and strict rules as well as a collective quest for adherence to these rules for the benefit of others (Drury et al. 2019). Experimental studies suggest that framing physical distancing as a means of protecting others increased intention to adhere to physical distancing directives more than messages prioritizing protecting oneself from COVID-19 (Jordan et al. 2020).

Descriptive social norms were also an independent predictor of physical distancing. In line with prior work (Rivis and Sheeran 2003), the more individuals perceived that other people were respecting physical distancing, the more likely they were to report full adherence themselves. Public messages aiming at shifting the perceived descriptive social norms by highlighting how common the adoption of preventive actions is may promote adherence to physical distancing (Sheeran et al. 2016). These results also have implications on how the portrayal of adherence or non-adherence in the media may influence perceived social norms. The media may promote adherence by regularly highlighting the individuals or groups who are adhering to governmental directives.

Consistent with other studies, females and older adults reported more physical distancing than males and younger individuals (Bish and Michie 2010). Furthermore, essential worker status was strongly associated with physical distancing. However, this likely reflects workrelated constraints rather than lack of compliance with sanitary directives. In a sensitivity analysis, social and cognitive correlates of physical distancing remained significant even when essential workers were excluded from the analysis.

There are a number of noteworthy non-significant predictors in the present study. In contrast to other studies using the health belief model, perceived barriers were not significantly associated with adherence (Carpenter 2010). Finding the confinement unpleasant, frustrating, financially costly, or difficult to apply in one's daily life was not significantly associated with physical distancing. Relatedly, despite significant bivariate associations with adherence, indicators of anxiety, depression, and loneliness were not independent predictors of physical distancing for the main sample. These results indicate that many people remain adherent to physical distancing despite its unpleasant psychological and financial consequences.

One of the limitations of this study is the use of a selfreported measure of physical distancing susceptible to social desirability bias. Furthermore, although people may intend to follow physical distancing, they may not recognize when they are not implementing it properly in their daily life. Moreover, the cross-sectional study design precludes us from determining the directionality of the observed relationships. Given that scientific understanding of COVID-19 is evolving quickly, prospective studies with frequent assessments will be needed to assess the changing dynamics in health beliefs, social norms, and adherence over time. Given the number of statistical tests performed, if a correction for multiple comparisons was applied, only injunctive personal norms and perceived benefits to others would remain independent correlates of physical distancing. Interpretation of these findings should be considered in light of sampling biases in this nonprobability sample. Participants were part of a web panel, which led to self-selection biases (Baker et al. 2010). In particular, individuals from the lowest education strata were under-represented in the present sample and no sampling weights were applied in the analyses to adjust for these sampling biases. The present findings may also be influenced by the local cultural and political context. Notably, in Canada, the different levels of government are sending largely consistent public health messages and polls revealed a high level of approval in the government handling of the crisis at the time of the survey (Léger Marketing Inc. 2020), suggesting significant trust in governmental institutions.

\section{Conclusion}

This study's findings indicate that individuals' beliefs about the benefits of physical distancing for others, the sense of civic duty to follow these directives, and the perceived descriptive social norms were independently associated with physical distancing. These results highlight the importance of these psychosocial factors in shaping community responses to a pandemic. The findings offer insights into potential social and cognitive targets for public health communication aiming at promoting physical distancing.

Author contributions All authors contributed to the study conception and design. Material preparation, data collection, and analyses were performed by Jean-Philippe Gouin, Sasha MacNeil, Andrew Switzer, Emily Carrese-Chacra, and Bärbel Knäuper. The first draft of the manuscript was written by Jean-Philippe Gouin and all authors commented on previous versions of the manuscript. All authors read and approved the final manuscript.

Funding This study was funded by a grant from the Quebec Research Network on Suicide, Mood Disorders, and Associated Disorders.

\section{Compliance with ethical standards}

The funding agency had no role in the study design and data collection, analysis, and interpretation, and decision to publish this manuscript.

Conflict of interest The authors declare that they have no conflict of interest. 


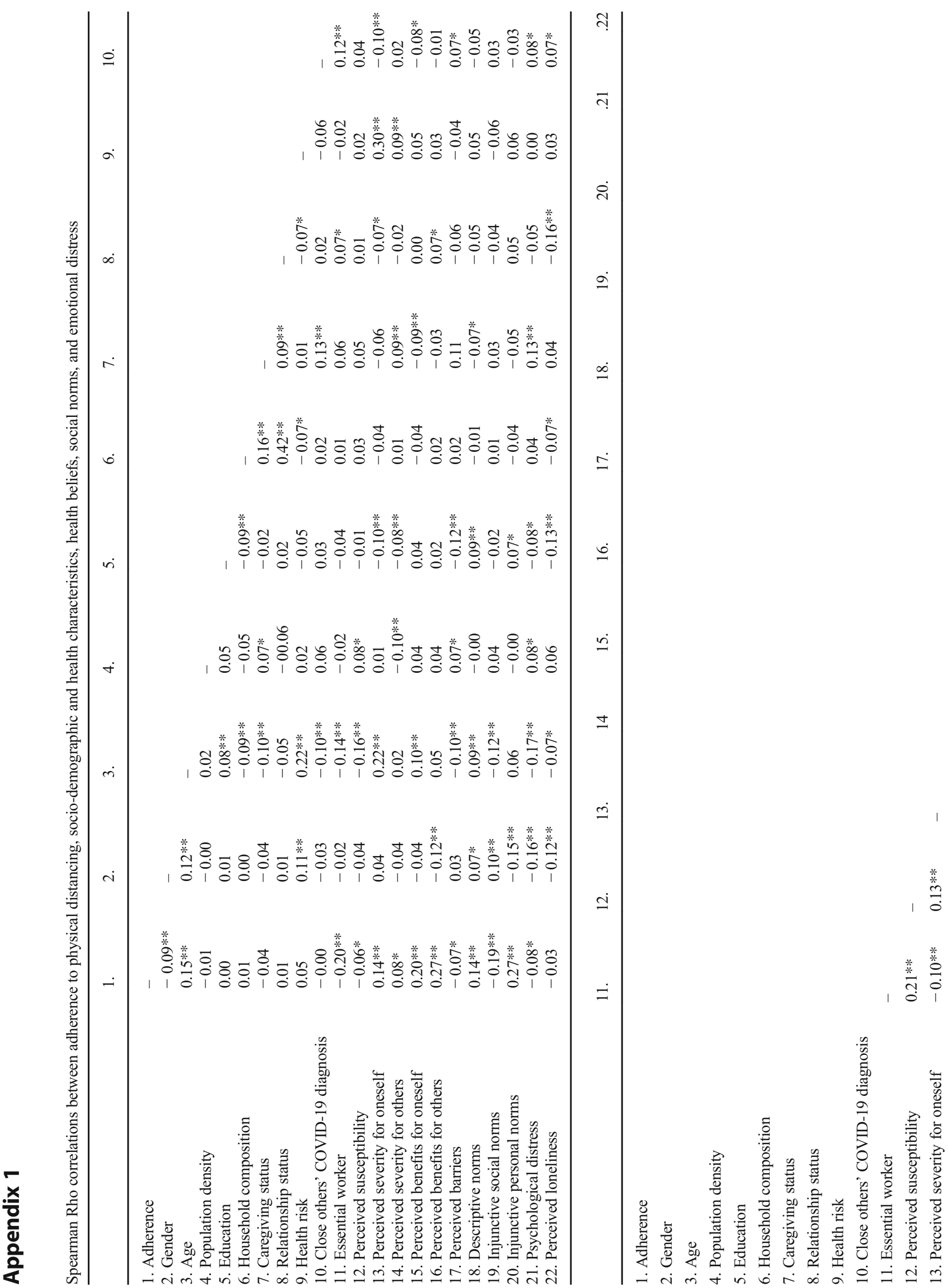




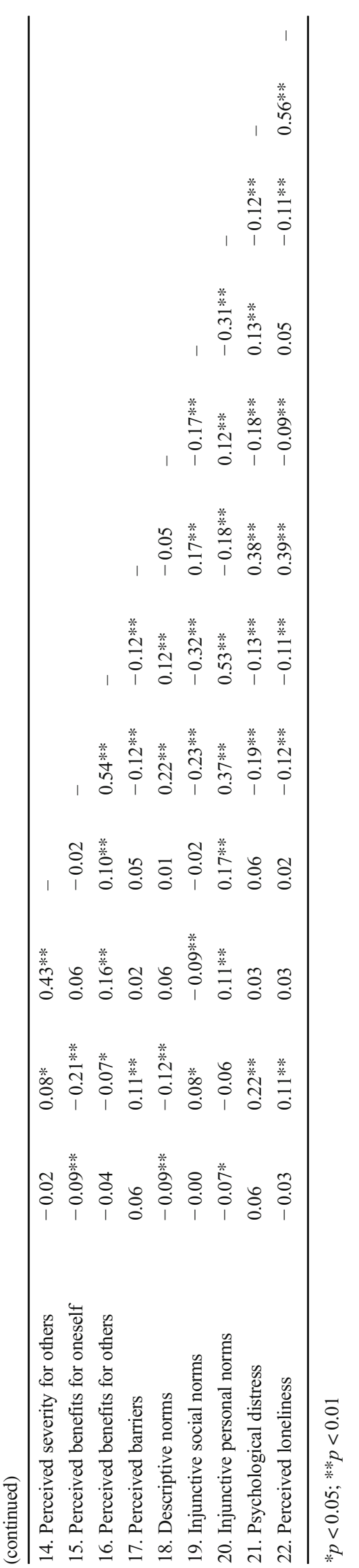




\section{Appendix 2}

Logistic regression models predicting adherence to individual physical distancing directives

\begin{tabular}{|c|c|c|c|c|c|}
\hline & $\begin{array}{l}\text { Minimize contact } \\
\text { by staying home } \\
\text { Odds ratio } \\
(95 \% \mathrm{CI})\end{array}$ & $\begin{array}{l}\text { Minimize non- } \\
\text { essential travel } \\
\text { Odds ratio } \\
(95 \% \mathrm{CI})\end{array}$ & $\begin{array}{l}\text { Avoid home visitors } \\
\text { Odds ratio } \\
(95 \% \text { CI })\end{array}$ & $\begin{array}{l}\text { Avoid gatherings } \\
\text { with }>2 \text { people } \\
\text { Odds ratio } \\
(95 \% \mathrm{CI})\end{array}$ & $\begin{array}{l}\text { Maintain 2-metre } \\
\text { distance } \\
\text { Odds ratio } \\
(95 \% \mathrm{CI})\end{array}$ \\
\hline Intercept & $\begin{array}{c}0.004 * * * \\
(0.001,0.025)\end{array}$ & $\begin{array}{c}0.002 * * * \\
(0.000,0.012)\end{array}$ & $\begin{array}{c}0.053 * * \\
(0.006,0.497)\end{array}$ & $\begin{array}{c}0.052 * * \\
(0.006,0.463)\end{array}$ & $\begin{array}{c}0.006 * * * \\
(0.001,0.037)\end{array}$ \\
\hline Age $(70+)$ & $\begin{array}{c}2.249 * * \\
(1.215,4.162)\end{array}$ & $\begin{array}{c}1.899 * \\
(1.070,3.373)\end{array}$ & $\begin{array}{c}1.956 \\
(0.776,4.931)\end{array}$ & $\begin{array}{c}1.726 \\
(0.690,4.319)\end{array}$ & $\begin{array}{c}2.105 \\
(0.990,4.447)\end{array}$ \\
\hline Gender (Male) & $\begin{array}{c}0.714 * \\
(0.527,0.968)\end{array}$ & $\begin{array}{c}0.847 \\
(0.626,1.146)\end{array}$ & $\begin{array}{c}0.991 \\
(0.645,1.524)\end{array}$ & $\begin{array}{c}0.618^{*} \\
(0.405,0.945)\end{array}$ & $\begin{array}{c}0.943 \\
(0.675,1.319)\end{array}$ \\
\hline Population density & $\begin{array}{c}1.000 \\
(1.000,1.000)\end{array}$ & $\begin{array}{c}1.000^{*} \\
(1.000,1.000)\end{array}$ & $\begin{array}{c}1.000 \\
(1.000,1.000)\end{array}$ & $\begin{array}{c}1.000 \\
(1.000,1.000)\end{array}$ & $\begin{array}{c}1.000 \\
(1.000,1.000)\end{array}$ \\
\hline Education & $\begin{array}{c}1.092 \\
(0.932,1.280)\end{array}$ & $\begin{array}{c}1.091 \\
(0.932,1.278)\end{array}$ & $\begin{array}{c}0.797 * \\
(0.638,0.996)\end{array}$ & $\begin{array}{c}1.189 \\
(0.953,1.483)\end{array}$ & $\begin{array}{c}0.949 \\
(0.799,1.127)\end{array}$ \\
\hline Household composition (> 1) & $\begin{array}{c}1.145 \\
(0.749,1.750)\end{array}$ & $\begin{array}{c}0.994 \\
(0.653,1.511)\end{array}$ & $\begin{array}{c}1.744 \\
(0.409,1.354)\end{array}$ & $\begin{array}{c}1.147 \\
(0.644,2.041)\end{array}$ & $\begin{array}{c}0.995 \\
(0.631,1.568)\end{array}$ \\
\hline Caregiving status $(\geq 1)$ & $\begin{array}{c}0.814 \\
(0.549,1.213)\end{array}$ & $\begin{array}{c}1.042 \\
(0.697,1.559)\end{array}$ & $\begin{array}{c}0.714 \\
(0.424,1.203)\end{array}$ & $\begin{array}{c}0.986 \\
(0.573,1.696)\end{array}$ & $\begin{array}{c}0.914 \\
(0.593,1.408)\end{array}$ \\
\hline Civil status (coupled) & $\begin{array}{c}0.925 \\
(0.658,1.301)\end{array}$ & $\begin{array}{c}1.050 \\
(0.749,1.473)\end{array}$ & $\begin{array}{c}1.405 \\
(0.887,2.225)\end{array}$ & $\begin{array}{c}0.817 \\
(0.512,1.304)\end{array}$ & $\begin{array}{c}1.495^{*} \\
(1.036,2.158)\end{array}$ \\
\hline Health risk (present) & $\begin{array}{c}1.155 \\
(0.832,1.601)\end{array}$ & $\begin{array}{c}0.891 \\
(0.644,1.233)\end{array}$ & $\begin{array}{c}0.915 \\
(0.576,1.453)\end{array}$ & $\begin{array}{c}1.106 \\
(0.700,1.746)\end{array}$ & $\begin{array}{c}1.399 \\
(0.969,2.020)\end{array}$ \\
\hline Close others' diagnosis (present) & $\begin{array}{c}0.955 \\
(0.632,1.441)\end{array}$ & $\begin{array}{c}1.129 \\
(0.745,1.711)\end{array}$ & $\begin{array}{c}1.130 \\
(0.630,2.025)\end{array}$ & $\begin{array}{c}1.089 \\
(0.617,1.922)\end{array}$ & $\begin{array}{c}1.257 \\
(0.799,1.979)\end{array}$ \\
\hline Essential worker (present) & $\begin{array}{c}0.329 * * * \\
(0.222,0.487)\end{array}$ & $\begin{array}{c}0.429 * * * \\
(0.288,0.638)\end{array}$ & $\begin{array}{c}0.943 \\
(0.538,1.653)\end{array}$ & $\begin{array}{c}0.867 \\
(0.509,1.475)\end{array}$ & $\begin{array}{c}0.640^{*} \\
(0.422,0.971)\end{array}$ \\
\hline Perceived susceptibility & $\begin{array}{c}0.951 \\
(0.801,1.128)\end{array}$ & $\begin{array}{c}1.210^{*} \\
(1.017,1.440)\end{array}$ & $\begin{array}{c}1.191 \\
(0.934,1.518)\end{array}$ & $\begin{array}{c}0.921 \\
(0.731,1.160)\end{array}$ & $\begin{array}{c}0.892 \\
(0.740,1.076)\end{array}$ \\
\hline Perceived severity for oneself & $\begin{array}{c}1.038 \\
(0.878,1.228)\end{array}$ & $\begin{array}{c}1.183^{*} \\
(1.001,1.399)\end{array}$ & $\begin{array}{c}1.028 \\
(0.814,1.299)\end{array}$ & $\begin{array}{c}1.039 \\
(0.821,1.313)\end{array}$ & $\begin{array}{c}1.198 \\
(0.995,1.443)\end{array}$ \\
\hline Perceived severity for others & $\begin{array}{c}1.075 \\
(0.913,1.266)\end{array}$ & $\begin{array}{c}1.035 \\
(0.879,1.218)\end{array}$ & $\begin{array}{c}1.167 \\
(0.932,1.461)\end{array}$ & $\begin{array}{c}1.231 \\
(0.982,1.542)\end{array}$ & $\begin{array}{c}1.064 \\
(0.891,1.271)\end{array}$ \\
\hline Perceived benefits for oneself & $\begin{array}{c}1.136 \\
(0.907,1.423)\end{array}$ & $\begin{array}{c}1.214 \\
(0.970,1.520)\end{array}$ & $\begin{array}{c}1.144 \\
(0.847,1.544)\end{array}$ & $\begin{array}{c}1.078 \\
(0.800,1.451)\end{array}$ & $\begin{array}{c}1.368 * * \\
(1.083,1.728)\end{array}$ \\
\hline Perceived benefits for others & $\begin{array}{c}1.450 * * \\
(1.127,1.865)\end{array}$ & $\begin{array}{c}1.772 * * * \\
(1.376,2.282)\end{array}$ & $\begin{array}{c}1.361 \\
(0.993,1.865)\end{array}$ & $\begin{array}{c}1.346 \\
(0.985,1.839)\end{array}$ & $\begin{array}{c}1.141 \\
(0.877,1.484)\end{array}$ \\
\hline Perceived barriers & $\begin{array}{c}0.982 \\
(0.832,1.159)\end{array}$ & $\begin{array}{c}0.839^{*} \\
(0.711,0.990)\end{array}$ & $\begin{array}{c}0.8377 \\
(0.664,1.056)\end{array}$ & $\begin{array}{c}0.832 \\
(0.678,1.020)\end{array}$ & $\begin{array}{c}1.039 \\
(0.866,1.245)\end{array}$ \\
\hline Descriptive social norms & $\begin{array}{c}1.164 \\
(0.953,1.422)\end{array}$ & $\begin{array}{c}1.181 \\
(0.967,1.441)\end{array}$ & $\begin{array}{c}1.373^{*} \\
(1.040,1.814)\end{array}$ & $\begin{array}{c}1.317 * \\
(1.010,1.719)\end{array}$ & $\begin{array}{c}1.469 * * * \\
(1.183,1.824)\end{array}$ \\
\hline Injunctive social norms & $\begin{array}{c}0.960 \\
(0.810,1.138)\end{array}$ & $\begin{array}{c}1.019 \\
(0.859,1.208)\end{array}$ & $\begin{array}{c}0.957 \\
(0.769,1.189)\end{array}$ & $\begin{array}{c}0.832 \\
(0.678,1.020)\end{array}$ & $\begin{array}{c}0.847 \\
(0.709,1.011)\end{array}$ \\
\hline Injunctive personal norms & $\begin{array}{c}1.888 * * * \\
(1.461,2.440)\end{array}$ & $\begin{array}{c}1.622 * * * \\
(1.263,2.083)\end{array}$ & $\begin{array}{c}1.767 * * * \\
(1.317,2.370)\end{array}$ & $\begin{array}{c}1.744 * * * \\
(1.301,2.337)\end{array}$ & $\begin{array}{c}1.694 * * * \\
(1.305,2.199)\end{array}$ \\
\hline Psychological distress & $\begin{array}{c}0.999 \\
(0.940,1.063)\end{array}$ & $\begin{array}{c}1.022 \\
(0.962,1.086)\end{array}$ & $\begin{array}{c}1.036 \\
(0.952,1.127)\end{array}$ & $\begin{array}{c}1.052 \\
(0.969,1.143)\end{array}$ & $\begin{array}{c}0.968 \\
(0.906,1.034)\end{array}$ \\
\hline Perceived loneliness & $\begin{array}{c}1.095 \\
(0.992,1.208)\end{array}$ & $\begin{array}{c}1.044 \\
(0.948,1.151)\end{array}$ & $\begin{array}{c}0.962 \\
(0.839,1.461)\end{array}$ & $\begin{array}{c}0.961 \\
(0.842,1.098)\end{array}$ & $\begin{array}{c}1.105 \\
(0.993,1.231)\end{array}$ \\
\hline
\end{tabular}

$* p<0.05 ; * * p<0.01 ; * * * p<0.001$ 


\section{References}

Anderson, R. M., Heesterbeek, H., Klinkenberg, D., \& Hollingsworth, T. D. (2020). How will country-based mitigation measures influence the course of the COVID-19 epidemic? Lancet, 395(10228), 931-934. https://doi.org/10.1016/S0140-6736(20)30567-5.

Baker, R., Blumberg, S. J., Brick, J. M., Couper, M. P., Courtright, M., Dennis, J. M., Dillman, D., Frankel, M. R., Garland, P., Groves, R. M., Kennedy, C., Krosnick, J., Lavrakas, P. J., Lee, S., Link, M., Piekarski, L., Rao, K., Thomas, R. K., \& Zahs, D. (2010). Research synthesis: AAPOR report on online panels. Public Opinion Quarterly, 74, 711-781. https://doi.org/10.1093/poq/nfq048.

Bi, Q., Wu, Y., Mei, S., Ye C., Zou, X., Zhang, Z., Xioajian, L., Wei, L., Truelove, S. A., Zhang, T., Gao, W., Cong, C., Xiujuan, T., Xioliang, W., Wu, Y., Binbin, S., Huang, S., Sun, Y., Zhang, J., Ma, T., ..., Feng, T. (2020). Epidemiology and transmission of COVID-19 in 391 cases and 1286 of their close contacts in Shenzhen, China: a retrospective cohort study. Lancet Infectious Disease, 20, 911-919. https://doi.org/ 10.1016/S1473-3099(20)30287-5.

Bish, A., \& Michie, S. (2010). Demographic and attitudinal determinants of protective behaviours during a pandemic: a review. $\mathrm{Br} J$ Health Psychol, 15(4), 797-824. https://doi.org/10.1348/135910710X485826.

Brooks, S. K., Webster, R. K., Smith, L. E., Woodland, L., Wessely, S., Greenberg, N., \& Rubin, G. J. (2020). The psychological impact of quarantine and how to reduce it: rapid review of the evidence. Lancet, 395(10227), 912-920. https://doi.org/10.1016/S0140-6736(20)30460-8.

Carpenter, C. J. (2010). A meta-analysis of the effectiveness of health belief model variables in predicting behavior. Health Commun, 25(8), 661669. https://doi.org/10.1080/10410236.2010.521906.

Cava, M. A., Fay, K. E., Beanlands, H. J., McCay, E. A., \& Wignall, R. (2005). Risk perception and compliance with quarantine during the SARS outbreak. J Nurs Scholarsh, 37(4), 343-347. https://doi.org/ 10.1111/j.1547-5069.2005.00059.x.

Cialdini, R. B., \& Goldstein, J. (2004). Social influence: compliance and conformity. Annu Rev Psychol, 55, 591-621 https://psycnet.apa.org/ doi/10.1146/annurev.psych.55.090902.142015.

DiGiovanni, C., Conley, J., Chiu, D., \& Zaborski, J. (2004). Factors influencing compliance with quarantine in Toronto during the 2003 SARS outbreak. Biosecurity Bioterrorism, 2(4), 265-272. https://doi.org/10. 1089/bsp.2004.2.265.

DiMatteo, M. R., Leppers, H. S., \& Croghan, T. W. (2000). Depression is a risk factor for noncompliance with medical treatment: meta-analysis of the effects of anxiety and depression on patient adherence. JAMA Intern Med, 160(14), 2101-2107. https://doi.org/10.1001/archinte.160.14. 2101.

Drury, J., Carter, H., Cocking, C., Ntontis, E., Guven, S. T., \& Amlôt, R. (2019). Facilitating collective psychological resilience in the public in emergencies: twelve recommendations based on the social identity approach. Front Public Health, 7(141), 1-21. https://doi.org/10.3389/ fpubh.2019.00141.

Everett, J. A. C., Colombatto, C., Chituc, V., Brady, W. J., \& Crockett, M. (2020). The effectiveness of moral messages on public health behavioral intentions during the COVID-19 pandemic. PsyArXiv. https://doi.org/ 10.31234/osf.io/9yqs8.

Gherson, R. R., Zhi, Q., Chin, A. F., Nwankwo, E. M., \& Gargano, L. M. (2018). Adherence to emergency public health measures for bioevents: review of US studies. Disaster Medicine and Public Health Preparedness, 12(4), 528-535. https://doi.org/10.1017/dmp.2017.96.

Gouvernement du Québec. (2020). COVID-19: plan d'action pour une deuxième vague (ISBN : 978-2-550-87363-1). Retrieved from https:// publications.msss.gouv.qc.ca/msss/document-002660/.

Grant, A. M., \& Hofmann, D. A. (2011). It's not about me: motivating hand hygiene among health care professionals focusing on patients.
Psychological Science, 22(12), 1494-1499. https://oi.org/10.1177/ 0956797611419172.

Hughes, M. E., Waite, L. J., Hawkley, L. C., \& Cacioppo, J. T. (2004). A short scale for measuring loneliness in large surveys: results from two population-based studies. Research on Aging, 26(6), 655-672. https:// doi.org/10.1177/0164027504268574.

Jordan, J., Yoeli, E., \& Rand, D. G. (2020). Don't get it or don't spread it? Comparing self-interested versus prosocially framed COVID-19 prevention messaging. PsyArXiv. Doi: https://doi.org/10.31234/osf.io/ yuq7x.

Kroenke, K., Spitzer, R. L., Williams, J. B. W., \& Löwe, B. (2009). An ultrabrief screening scale for anxiety and depression: the PHQ-4. Psychosomatics, 50(6), 613-621. https://doi.org/10.1016/S00333182(09)70864-3.

Léger Marketing Inc. (2020). Préoccupation face à la COVID-19 - 24 mars 2020. https://leger360.com/fr/sondages/preoccupation-face-a-la-covid19-24-mars-2020/. Accessed 4 May 2020.

Leung, G. M., Lam, T. H., Ho, L. M., Ho, S. Y., Chan, B. H. Y., Wong, I. O. L., \& Hedley, A. J. (2003). The impact of community psychological responses on outbreak control for severe acute respiratory syndrome in Hong Kong. J Epidemiol Community Health, 57(11), 857-863. https:// doi.org/10.1136/jech.57.11.857.

Manstead, A. S. R. (2000). The role of moral norm in the attitude-behavior relation. In D. J. Terry \& M. A. Hogg (Eds.), Applied social research. Attitudes, behavior, and social context: the role of norms and group membership (pp. 11-30). Mahwah, NJ: Lawrence Erlbaum Associates Publishers.

Rivis, A., \& Sheeran, P. (2003). Descriptive norms as an additional predictor in the theory of planned behaviour: a meta-analysis. Current Psychology: A Journal for Diverse Perspectives on Diverse Psychological Issues, 22(3), 218-233. https://doi.org/10.1007/s12144003-1018-2.

Rivis, A., Sheeran, P., \& Armitage, C. J. (2009). Expanding the affective and normative components of the theory of planned behavior: a metaanalysis of anticipated affect and moral norms. J Appl Soc Psychol, 39(12), 2985-3019. https://doi.org/10.1111/j.1559-1816.2009.00558.x.

Rosenstock, I. M. (1974). Historical origins of the health belief model. Health Education Monographs, 2(4), 328-335. https://doi.org/10. 1177/109019817400200403.

Segrin, C., \& Passalacqua, S. A. (2010). Functions of loneliness, social support, health behaviors, and stress in association with poor health. Health Commun, 25(4), 312-322. https://doi.org/10.1080/ 10410231003773334.

Sheeran, P., Maki, A., \& Montanaro, E. (2016). The impact of changing attitudes, norms, and self-efficacy on health-related intentions and behavior: a meta-analysis. Health Psychol, 35(11), 1178-1188. https://doi.org/10.1037/hea0000387.

Statistics Canada. (2017). Population center and rural area classification 2016. https://www.statcan.gc.ca/eng/subjects/standard/pcrac/2016/ introduction.

Taylor, M., Raphael, B., Barr, M., Agho, K., Stevens, G., \& Jorm, L. (2009). Public health measures during an anticipated influenza pandemic: factors influencing willingness to comply. Risk Management and Healthcare Policy, 2, 9-12. https://doi.org/10.2147/RMHP. S4810.

Webster, R. K., Brooks, S. K., Smith, L. E., Woodland, L., Wessely, S., \& Rubin, G. J. (2020). How to improve adherence with quarantine: rapid review of the evidence. Public Health, 182, 163-169. https:// doi.org/10.1101/2020.03.17.20037408.

Publisher's note Springer Nature remains neutral with regard to jurisdictional claims in published maps and institutional affiliations. 